Original Contribution

\title{
EFFECT OF MUSIC ON CHILDREN'S NATURE AND BEHAVIOUR. HOW MUSIC CAN EDUCATE, BUT ALSO DESTROY
}

\author{
E. Georgieva* \\ Department of Social Activities, Faculty of Medicine, Trakia University, Stara Zagora, Bulgaria
}

\begin{abstract}
This article raises the question of the influence of music on the physical, emotional and mental development of children. Why has it got such power? What are the powerful effects it has on the brain? What is the counterproductive influence of music? Which music develops the virtues and which destroys? These are questions the answers to which were known even to ancient philosophers.
\end{abstract}

Key words: effect of music on man, impact of music on the brain, what music should our children listen to.

Numerous factors nowadays have a detrimental effect on our children: computer games, children's programmes, telephones, tablets, lack of motivation, collapsed family structures, school impersonality and many other known and unknown destroyers. It is not enough anymore, much to our regret, for the parent to demand and know the way. Children have a growing resistance to any spiritual activity. The process of eroding the vital pillars of society is in its heyday. Our language has become impoverished and reduced to the elementary needs of everyday life, and numerous brain cells have degenerated. In general, health, spiritual and emotional growth of children are not priorities of the educational system. Children do not eat properly, they are not physically active, and they do not read books and are not motivated to do meaningful activities. Contemporary generations actively degrade and turn right before our eyes into spiritually devastated and crippled young people. How long will it be like this and what can we, the parents as the smallest link in the system, do? A return to simple things with true eternal value and easy to understand, quickly applicable methods, is the key, the pearl of conscious action, which if applied consciously and consistently in all spheres of everyday life, will inevitably lead to a positive result. "There will come a time when people will slow down

*Correspondence to: Elitsa Georgieva, Trakia University, Faculty of Medicine, Department of Social Activities, 11 "Armeiska" street, 6000, Stara Zagora, Bulgaria and start to appreciate things like books. Literature is a slow medium. Reading a book takes a day or longer, but then its meanings will have a lasting hold on you. Literature means duration.", says Georgi Gospodinov, a holder of a $\mathrm{PhD}$ degree in contemporary Bulgarian literature at the Institute of Literature, Bulgarian Academy of Sciences (1).

The present day is a time of extremes and determination. There are two ways and the decision remains entirely in our hands. "Slow food" or "fast food", knowledge at all levels or illiteracy at all levels, Renaissance or Middle ages. The problems are nationwide, common, involving every one of us, no matter which country we are in. So, decisions can be antipodal, that is, diametrically opposed. The power of the "tool" we apply is exceptionally high both in the positive and negative direction. We enroll our children in judo, violin, tennis, singing, drawing, Chinese, English classes.... and yet we do not know what to demand, expect, observe. And instead of slowing down the pace, focusing on the main, leaving aside the details, and approaching the things which are "simpler", but stronger in terms of efficiency, we start in the reverse direction and reinforce the negative effect. Music is one of those "tools" that strongly influence children and all of us - brain structures, emotions, soul, actions and understanding. It is a "slow medium" with long and sustainable impact. 
Why music has an exceptionally strong effect on people? Man can be compared with a very complex and finely tuned musical instrument. Each atom, molecule, cell, tissue and organ of the body constantly emit frequencies.

Compliance of the frequencies of musical sounds with the structural pattern of tissues and organs in the human and compliance of the music beat with the rhythms of the processes of his or her life results in the fact that music, following the principle of acoustic resonance, has very deep and multi-faceted impact on all functions of the human body (blood circulation, digestion, breathing, inner secretion, activity of the nervous system and the brain). This inevitably affects emotions, desires, feelings. When sound waves penetrate the human body, nice vibrations occur in its cells. The high water content in the tissue facilitates the transmission of the sound. The total mechanical effect of that can be compared with deep massage on an atomic and molecular level.

According to T. Mikushina, "Music is a flow of energy. It directs our emotions, reason and mood. Music is a force that can be used for both good and evil. It is a factor that guides the development of civilization. The music that distorts the harmony of sound and the rhythm of life itself - slowly, but irreversibly destroys man, his/her psyche, morality, soul, mind, emotions, body..." The sound is a universal powerful invisible force capable to cause both favourable (joy, inspiration, healing, relaxation, peace...) and destructive changes (irritation, disorientation, oppression, devastation, sickness, even death)." The world is full of sounds. We live in a world full of weak and strong, unusual and familiar, disordered and ordered, soothing and irritating, healing and detrimental, music and noise sounds that we hear or not hear. Musical sounds differ from other sounds in that their frequencies are related to each other in certain proportions (harmonics). These proportions can be observed in the entire diversity of natural phenomena - from the development of the cell and the plant to the movement of planets around the Sun, and in the man-made world - architecture, art, mathematics. The musical sounds making up a piece of music are subject to a certain rhythm. The familiar rhythms of $4 / 4,2 / 4,3 / 4,6 / 8 \ldots$ have direct correlation with the rhythms of the life processes of man.", T. Mikushina writes in her study of music.

Music acts on the body in two different ways: by direct influence of sound on the cells and organs and by indirect influence on emotions, which in turn affects many processes in the human body. In his book "The Secret Power of Music" David Tame states that there is not a single function in the human body unaffected by music, "The study showed that music has effect on digestion, inner secretion, circulation, feeding and breathing ... ". Cyril Scott (18791970), a famous English pianist and composer, in his work "Music: Its Secret Influence Throughout the Ages" reveals the new importance of music and its influence on the consciousness of nations. According to the author, each type of music has a strong influence on the history, morality and culture of mankind. Until now it has been thought that each type of music was born from the environment of its inherent cultural era. Scott reversed everything arguing that cultural epochs were created by music. According to Plato, "Musical training is a more potent instrument than any other, because rhythm and harmony find their way into the inward places of the soul... Musical innovation is full of danger to the whole State and ought to be prohibited, for when modes of music change, the laws of the State always change with them". (3)

"In Plato's work music is regarded as a basic science, mandatory in the education of children. In the "Republic" he offers a high moral standard for education, one of the ways of education being through music - sounds, rhythms and spoken words. His idea is that just as the body develops by physical exercise, so the soul feeds on good literature, fine music and, above all, philosophical truth. In a broader sense Plato's understanding of harmony means love, order, agreement, unity in plurality, commensurability and proportion. Harmony "consists of physical parts, but its meaning is the love that unites its constituent opposites, and such meaning and love are not physical" (3). He takes and develops further the ideas of the Pythagoreans about numerical proportions in music." (4)

Slow music affects the human heart rate. According to researchers, fast tempo music results in increase of the heart rate and arterial blood pressure, while slower music reduces the heart rate. Music does much more than slow heart rate. It can sharpen mental abilities and is a means to relieve tension by increasing the release of endorphins by the body. Music produces powerful effects on the brain (one should not forget the antipodal model role), promotes the development of cognitive abilities, verbal skills and emotional intelligence. Musical training has a profound, positive effect on the brain for the cognitive 
functions, and IQ results and specific skills (such as literacy, visual, verbal and mathematical memory) are improved. Music can create better readers. Brain responses during music performing improve the same communication skills needed for speaking, reading, vocabulary and pronunciation. Music is also a whole different language through which communication is made between it and the brain. It develops emotional intelligence. Latest studies have shown that musical training improves the child's ability to express emotion through sound. When music is taught in the classroom, it helps children to acquire useful skills for listening and concentration, provokes their patience and perseverance, which are important for the future and coping with life's problems. G. Suvorov, a Ukrainian cyber specialist, shared his fears that already seem to be a reality, "We have every reason to talk about "scissors" between the emotional and intellectual development of a person. Intellectual development often overtakes the emotional one. The danger lies not in the fact that machines will begin to think like people, but that people will begin to think like machines. If the child is not brought up emotionally, it will become a robot. It will cease to dream, love and empathise." The renowned educator Suhomlinski noticed that juvenile delinquents living in detention centres did not like serious music. "We think this is not accidental", Anatoly Zak, a child psychologist, and Lev Madorskiy, a music school teacher, wrote in their article "Music education and health", "Classical music affects positively the spiritual and emotional nature of man. At the same time, the lost interest of young people to serious music and increased juvenile delinquency worldwide are parts of one and the same chain." (5) Therefore, music saves literally - not only at an emotional level for spiritual elevation and other virtues, but it has an exceptionally strong anti-criminal effect. Neurologists (Neuroscience 2013 conference of scientists and neurologists in San Diego) found that musical training increased brain volume and strengthened communication between brain areas! The knowledge of a musical instrument changes the way the brain interprets and integrates a wide range of sensory information. Experts at Harvard Medical School conclude that the research conducted on music and the brain suggest new roles of musical education, including promoting plasticity of the brain and treatment of a number of cognitive disorders. It is important what is the message we want to communicate to the child and what music the child often listens to. Music shapes perceptions and is directly related to the senses, including the visual ones. That is why, we should not leave the child for a long time in front of a TV listening to music and subconsciously perceiving degraded values flooding the music channels, and exerting a profound effect on the unspoiled and pure hearts!

"Why does your child study music?" eightytwo parents were asked by a Moscow music school. Sixteen replied, "To be able to play an instrument", twenty-one "for general knowledge", thirty-six "we want him/her to become a musician", eight "to love music" and only one: "not to become an evil person". The latter answer is of special importance (not only for Anatoly Zak and Lev Madorskiy who made the enquiry). This answer shows what the mission of modern musical pedagogy should be: the main task of mass musical education is not so much music training as is the influence through music on the spiritual world of the child.

Thus:

1. Music provides musical culture

2. Music lessons cultivate labour skills

3. Music classes develop coordination

4. Music classes boost the intellect

5. Music exerts influence through three basic

factors - vibration, physiological and

psychological.

6. Music contains the three "beginnings of all

living things" - rhythm, melody, harmony

7. Music allows precise dosing of mental and physical workload. Children recover without noticing the treatment process

8. Music allows to improve the breathing function

9. Music excites emotions and thus restores the immune biological processes by enhancing the emotional tone and positive emotions,

immunity is also enhanced.

However, certain music can have a counterproductive effect. "Avoid music that has harmful effects", Pythagoras advised. Music invades our lives forcefully from TV screens and at public places in shops and buses. Some types of music have a harmful effect on our body comparable with the use of drugs, alcohol, cigarettes. But if a man can give up drugs, alcohol, cigarettes by one's free will, music is imposed in a compulsory way and has a lasting effect. As there are bans on certain words, similarly there should be a ban on certain sounds. And particularly, those which, according to Pythagoras, have a "harmful effect" on man. It is no coincidence that around concert halls where hard rock is played are present law enforcement officers. And it is no coincidence that after Nova Rock music festival patients with mental disorders 
increase drastically. After such "concerts" the teenager audience whose mentality is easily vulnerable, becomes highly aggressive. The music that can be described as harmful is characterized by its frequent dissonance, lack of form and irregular rhythm. Any loud music leads to nervous breakdown. The arteries begin to shrink and obstruct blood flow to the heart at sound level of 70 decibels. In recent years, more and more widely spread are musical subgenres in which the number of beats per minute reaches 240 , or $4 \mathrm{GHz}$ !!! Such music lowers the frequency of vibration of the body which leads to a reduction of awareness or perception of reality. In other words, people who listen to such music lose control of their thoughts, emotions and behaviour. According to Professor B. Rauch, listening to hard rock leads to the release of the so-called stress hormones that erase a significant part of information from the brain. American physicians, headed by scientist Robert Larson, argue that the repetitive rhythm and low frequency vibrations of the bass guitar influence strongly the condition of the cerebrospinal fluid, and consequently, the functioning of the glands that regulate the secretion of hormones; the level of insulin in the blood changes significantly; the main indicators of moral restraint fall either below the tolerance level or are completely neutralized. At the genetic level, the "harmful" music induces very strong destruction: it literally "breaks down" the DNA molecules. Whereas classical music has just the opposite effect. The programming power of music can be channelled both for creativity and for destruction. The deep disintegration of society, moral values and the spread of negative emotional states (distrust, fear, hostility, aggression, depression and anxiety) are all consequences of the change of the acoustic rhythm, that is, the rhythm of vibrations. The essence of this impact (confirmed by science) is that dulling of the mind occurs, the most subtle and sublime emotions of the soul are destroyed and die. This rhythm is a rough irritant of the sexual nerve center, prompting it to a prematurely increased activity, physically leading the man to a storm of vile emotions and passions. Hypnosis experts claim that sequences of beats repeated many times induce hypnosis. Thus, people with nervous disorders are very susceptible to anything that is "preached" by the lyrics of such music. Therefore, seemingly normal teenagers behave like crazy at rock concerts and sometimes perform unexpected actions under the influence of drugs and alcohol. Ancient Greeks understood the importance of musical education more than today. By selecting appropriate music pieces teachers endeavoured to develop in the young Greeks qualities such as kindness, honesty, valour.

The human brain grows and develops thanks to its constant use. According to psychologist and memory expert Tony Buzan, "Your brain is made of a trillion brain cells. Each brain cell is like the most phenomenally complex little octopus. It has a center, it has many branches, and each branch has many connection points. Each one of those billions of brain cells is many times more powerful and sophisticated than most of the computers around the planet today. Each one of these cells connects, embraces, hundreds of thousands to tens of thousands of others. And they shuttle information back and forward. It's been called an enchanted loom, the most astoundingly complex, beautiful thing in existence. And each person has one." (12) If this enchanted loom is not in active use, it will be detrimentally affected!!! Cells reduce their function, parts of the incredible miracle, that each of us has, die. Due to this fact, not only the hyperactivity and attention deficit syndrome become epidemic. According to Dr. Psota (14), dementias "rejuvenate". Age is not the decisive factor for their manifestation. The favourite leisure "activities" of the young generation such as electronic games, media addiction, inactivity, no reading, long hours of listening to a certain type of music contribute actively to the death of the wonderful brain cells and filling the capacity of psychiatric wards with young old people. Neurophysiologist Glenn Doman together with a group of scientists founded in 1955 the Institutes for the Achievement of Human Potential in Philadelphia. Developing a rehabilitation system for children with severe damage to the central nervous system, he concluded that reading, mathematics and music have the greatest effect on the child's intellectual development. Thus, the idea to use the experience from stimulation of mental processes in the work with normal children was born. Through music sustainable emotional states are imprinted into the child. Upon repetition, they occur slightly once again thus resulting in the development of emotional patterns that become part of the character. In today's mass school the goal is to create musical culture needed to guide students through the diversity in music and as a component of their overall development.

Therefore, as guardians, teachers and parents, it is our task to pay attention to children what music to listen to and explain the strength of its impact. 
And Plato's words do not need any comment: " Musical training is a more potent instrument than any other, because rhythm and harmony find their way into the inward places of the soul, on which they mightily fasten, imparting grace, and making the soul of him who is rightly educated graceful."

\section{REFERENCES}

1. Gospodinov G., Novi medii i novi mladi (New media and new young people)

2. Scott C., Music: Its Secret Influence Throughout the Ages. 1933

3. Plato, The Republic

4. Stefanova P., Musikata i etosat - njakoi istoricheski aspekti (Music and the ethos some historical aspects)

5. Madorskiy L., Zak A., Muzikalnoe vospitanie i zdorove (Music education and health)

6. Madorskiy L., Zak A., Kak pravilno sozdat dlya detey muzikalnuyu sredu (How to correctly create a musical environment for children)

\section{GEORGIEVA E.}

7. http://letidor.ru/article/kak_pravilno_sozdat dlya_detey_129188/

8. https://www.edna.bg/za-roditeli/syveti/kakmuzikata-vliiae-vyrhu-razvitieto-na-decata4628297

9. http://letidor.ru/article/zachem_zanimatsya_ muzykoy_s_re_131208/

10.http://www.7ya.ru/article/zachem-rebenkumuzyka-chast-1/

11.http://www.umniche.com/wpcontent/uploads/logo-03.png

12.Buzan T., Master Your Memory

13.Buzan T., Mind Maps for Kids

14.Psota,G., Dr.Prim, Demenz-Versorgung und Behandlung

15.http://logosabv.com/wpcontent/uploads/2016/06/LogosABV.pdf

16.Mikushina T., Zvukat, ritamat i tyahnoto vazdeystvie varhu choveka (Sound, rhythm and their effect on the human)

17.Tame D., The Secret Power of Music 